\title{
The Environmental Costs of Water Flow Regulation: an Innovative Approach Based on the 'Polluter Pays' Principle
}

\author{
Silvestre García de Jalón ${ }^{1}$ • Marta González del Tánago ${ }^{2}$ • \\ Carlos Alonso $^{2}$ - Diego García de Jalón ${ }^{2}$
}

Received: 28 February 2016 / Accepted: 7 April 2017 /

Published online: 24 April 2017

(C) The Author(s) 2017. This article is an open access publication

\begin{abstract}
The EU Water Framework Directive (WFD) explicitly requires the full cost recovery of water services, including the environmental costs incurred from the damage that water uses inflict on the environment. Although flow regulation by river damming is one of the most prominent human impact on fresh water ecosystems its environmental costs are not properly included in water pricing. This paper presents a novel approach to assessing the environmental costs of flow regulation based on the polluter-pays principle. The methodology includes three steps: $(i)$ assessing the admissible range of regulated flow variability, derived from the natural flow regime variability, (ii) estimating the daily environmental impact of regulated flows according to deviations from the admissible range of flow variability, and (iii) calculating the environmental costs of flow regulation. The procedure is applied to four river case studies in Spain, UK and Norway. The advantages over other water cost valuation methods are discussed. The methodology enlarges the current recognition of environmental costs of water use and represents a practical management tool within the WFD context, encouraging transparency and stakeholder communication.
\end{abstract}

Highlights:

- A methodology to assess the environmental costs of flow regulation by dams is presented

- The polluter-pays principle is applied to calculate costs proportionally to hydrological alterations

- The method enlarges the current environmental costs recognition within the WFD

- It measures environmental costs of river damming with advantages over stated preference techniques

- It represents a practical management tool and encourages transparency and stakeholder communication

Silvestre García de Jalón

s.garcia-de-jalon@cranfield.ac.uk

1 Institute for Resilient Futures, Cranfield University, Cranfield MK43 0AL Bedfordshire, UK

2 Department of Natural Resources and Systems, Universidad Politécnica de Madrid, E.T.S.I. Montes, Forestal y del Medio Natural, 28040 Madrid, Spain 
Keywords Environmental costs · Flow regulation · Environmental impact · Valuation · Water

\section{Introduction}

In recent decades, economic assessments have assumed a key role in water policy, providing valuable information to support the sustainable development, conservation and use of water resources (Turner et al. 2000; Balana et al. 2011). As water resources become increasingly scarce relative to demand (as observed in dry regions and in many Mediterranean countries), calculating the economic value of water (including resource and environmental costs) will be essential to guide maximization of water's beneficial use (Garrote et al. 2015). An imperative condition for sustainable water management is the understanding and proper valuation of its full value. Bithas (2008) defined sustainable use of water as the avoidance of losing social welfare in the use of water, and presents water pricing as the practical means towards approaching efficient use. The study also states that full cost pricing can be justified as an instrument that promotes social equity in the long run, since egalitarian pricing that proposes low prices causes increased scarcity; which will induce a process of progressively increasing water prices which will inevitably increase also egalitarian prices. Many past failures in water resources management may be attributable to the fact that the full value of water has not been recognized (GWP, Global Water Partnership 2000). Recognizing the full value of water is important for the rational allocation of water as a scarce resource, whereas charging for water value may represent an economic instrument to affect behaviour towards conservation and efficient water usage (Pérez-Blanco et al. 2015), and ensures full cost recovery when environmental costs are properly internalized (Bithas 2006; Cooper et al. 2014). Thus, there is a clear need for operational economic instruments that can contribute to sustainable water management. These instruments should include practical procedures for environmental cost assessments that justify charges for water goods and services by reflecting the full cost involved.

The European Water Framework Directive (WFD) (EC, European Commission 2000) explicitly requires economic analysis of water use for two purposes: $(i)$ assessing the degree of cost recovery of water services, and (ii) estimating the potential costs of restoration measures. The WFD considers environmental and resource costs and explicitly states that water pricing policies should provide adequate incentives for users to efficiently use water resources. Since the common implementation strategy for the WFD (WATECO 2003), many attempts have been made to incorporate the principle of cost recovery into the assessment of water services by articulating key issues, methods and applications of economic principles (e.g., Balana et al. 2011; Berbel et al. 2011; Bithas et al. 2014). Despite these efforts, water users still do not pay the full cost of water supply (e.g., Berbel et al. 2011). Environmental costs are the least likely to be fully recovered, partially due to the complexity of nonmarket valuation. There is a need for research assessing the environmental costs of water uses, also considering the effects of different biophysical and socio-economic settings.

Environmental costs have been defined as the costs of damage that water uses impose on the environment and ecosystems (WATECO 2003). To evaluate both the use and non-use values of the goods and services of ecosystems, economists have commonly relied on stated preference techniques, in which willingness to pay (WTP) for environmental improvements or willingness to accept (WTA) compensation for environmental damage is estimated (Bateman et al. 2004; Martín-Ortega et al. 2011). These methods are based on people's expressed 
preferences for changes in provision of non-marketed goods and services (Bateman et al. 2004; Hanley and Barbier 2009). Despite having been widely used in environmental and resource valuation, these methods can suffer from several limitations, such as a lack of accurate estimates, subjectivity in the way of asking the questions, and, fundamentally, a lack of knowledge among respondents or difficulty in answering WTP/ WTA questions (Hanley and Barbier 2009).

Sustainable use of any resource relies on the action of a number of regulatory mechanisms that prevent the user from reducing the ability of the system to provide services. 'Polluter pays' principle was conceived as a way to proportionally allocate the effects of such alterations to those users that are responsible for them, thus producing a regulatory effect on the use of the resource. The European WFD, and more specifically the Environmental Liability Directive (EC, European Commission 2004), encourages the application of the "polluter-pays principle." Both Directives consider this principle to be fundamental to the recovery of costs for water services, as well as to the estimation of both environmental costs and costs of measures to achieve WFD objectives (WATECO 2003). To link water price to the impact that is produced by its use can be, therefore, an effective way to quantitatively regulate the use we make of water resources, preventing an overexploitation that will, in turn, reduce the amount of available water, and promoting a sustainable and efficient use of it (Bithas 2008). The challenge lies in applying this principle to all mechanisms involved in water availability (magnitude, timing, location and quality) and to water use value. The polluter-pays principle has been traditionally applied to water users who impact the quality of water bodies, more precisely to water supply to urban areas or industries producing water pollution or eutrophication (e.g., Balana et al. 2011; Bithas et al. 2014). However, there has been less effort to apply this principle to other water uses that heavily impact water quantity, such as irrigation for agriculture. Irrigated lands relies on intensive flow regulation by dams and reservoirs, using water that has been stored in the reservoirs during the colder and wetter months and is released from the dams during the dry and warmer periods (Tran et al. 2016). This type of flow regulation causes strong physical homogenization of river discharges and severe environmental impacts (Poff et al. 2007).

Flow regulation by dams and reservoirs is practiced worldwide (Lehner et al. 2011). The environmental impact of flow regulation has been widely documented (see Poff and Zimmerman 2010). River damming alters water and sediment flows (Vörösmarty et al. 2003) and affects the river hydro-morphological and biological components in many ways (Bunn and Arthington 2002) which is a major threat to river biodiversity at global scale (Poff et al. 2007). Despite this general agreement on the negative impacts of flow regulation, there has been little effort to quantify their environmental costs and their potential to influence water pricing. Although many attempts have been done to assessing environmental flows (e.g. Godinho et al. 2014) no practical tools have been developed to internalize the environmental costs of flow regulation in economic analysis in the context of the WFD (e.g. WATECO 2003; Martín-Ortega et al. 2011).

Our research contributes to the existing literature by developing an innovative approach to assessing the environmental costs of river damming. This approach applies the polluter-pays principle (in our case, the regulator-pays principle) and proposes that environmental costs increase proportionally or exponentially to the increase in the intensity of flow regulation. Although our methodology may be applied to any case of flow regulation, it is particularly addressed to water use for irrigation, where there is great potential for improving water use efficiency. Our purpose is to create a practical tool for: $(i)$ the design of adequate water pricing 
that encourages decreasing the environmental impacts and increasing efficiency in water use, and (ii) facilitating transparency and stakeholder communication in decision-making processes, in pursuit of achieving the WFD's economic and environmental objectives.

In this paper, the proposed methodology is explained and four examples of how the methodology applies to different European regulated rivers are shown. We include a brief introductory overview of Spanish water pricing policy as a necessary background to fully implementing our method in the Spanish case studies. Finally, we discuss the strengths and limitations of the proposed approach and discuss some potential improvements for further research.

\section{Methodology}

The methodology aims to estimate the environmental costs of flow regulation as a necessary complement to the current water tariffs applied to impounded rivers.

The procedure follows three consecutive steps: $(i)$ estimating the admissible range of variability of the natural flow regime in a river reach; (ii) quantifying the daily environmental impact due to the difference between current circulating flow and the admissible range of variability; and (iii) calculating the environmental costs considering site-specific particularities (e.g., vulnerability or conservation status of the river) or other seasonal or geographical circumstances. The methodology has been applied using $\mathrm{R}$ software. The $\mathrm{R}$ script is available from the corresponding author upon request.

\subsection{Admissible Range of Regulated Flow Variability}

Flow variability is an intrinsic attribute of the natural flow regime that must be preserved to maintain good ecological status of rivers (Poff et al. 1997). As a first step of our approach, the natural flow variability of the river is estimated using flow data from before the flow was regulated (i.e., data from the pre-dam period). The natural annual hydrograph of the reach is characterized by an area that covers the range of daily flows fluctuation.

Based on the observed natural daily flow fluctuations, the admissible range of regulated flow variability is defined and used to calculate the environmental impact of flow regulation. Thus, any variation of the regulated daily flows within this range may be considered "admissible" and any variation outside of the admissible range would be considered an environmental impact.

The admissible range is defined as the range of values between the 10th and 90th percentiles of each natural daily flow (see Fig. 1). The selection of percentiles 10 and 90 for delineating this admissible range might be subjective and they remain open to discussion. However, if no percentiles were selected the admissible flow variability would be equal to the total variation of flow under natural conditions. Consequently, it would be too broad to quantify the environmental impact or hydrologic alteration. For instance, if under natural conditions the river dries up once every hundred years, we would assume that in that specific time of the year water regulators could dry up the river every year without producing any substantial impact. For this reason, while it is crucial to exclude extreme values in the calculation of the admissible range, it is important to encompass the whole range of variability within which an impact is "admissible". To overcome the expected wide variability of these daily percentiles within the relatively short periods of pre-dam 

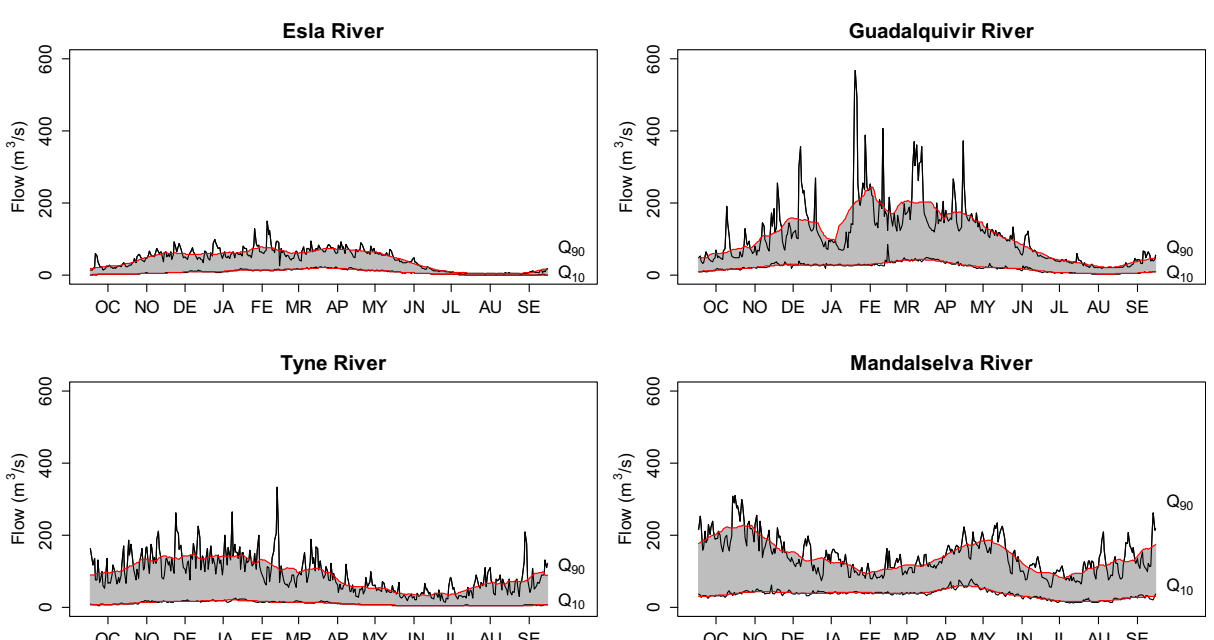

Reference flow from non-regulated period, 1957-1987 $\left(Q_{10} \& Q_{90}\right)$
Smoothed reference flow $\left(Q_{10} \& Q_{90}\right)$
Admissible range of regulated flow variability

Fig. 1 Admissible range of flow variability based on data from the non-regulated period. The grey area shows the admissible range of regulated flow variability, the black line shows the 10th and 90th percentiles during the pre-dam period, and the red line shows the smoothed upper and lower limits calculated by a moving average with 30 lags (days)

data, the upper and lower curves of the admissible range are smoothed by a moving average with thirty lags (30 days).

\subsection{Estimation of the Environmental Impact of Altering Magnitude, Timing and Duration of Flows}

The environmental impact of flow regulation is referred to changes in the natural patterns of the flow regime (Richter et al. 1996). As the main objective of our study was the evaluation of environmental costs on a daily basis, only flow variables that could express daily hydrologic alteration were considered.

Environmental impact is calculated for each year as the divergence between the currently regulated circulating flow and the admissible range of flow variability. Thus, the environmental impact can either be due to discharges higher than the upper limit of the admissible range (High-flow impact) or to discharges lower than the lower limit (Low-flow impact) of the admissible range. Figure 2 shows how the Low-flow and High-flow impacts of the regulated flow regime are calculated. The lower graphs show the estimated admissible range of regulated flow variability and the circulating flow in 2010 downstream of the dam. The upper graphs show the Low-flow and High-flow impacts calculated as the deviation from the admissible range of regulated flow variability.

Equations 1 and 2 quantify daily High-flow and Low-flow impacts of the current circulating flow in the day $d$ of year $y$. Both impacts are calculated as the distance from the upper limit of the admissible range of flow variability (High reference flow) and the lower limit (Low reference flow). To standardize the estimated High-flow and Low-flow impacts between 0 and 

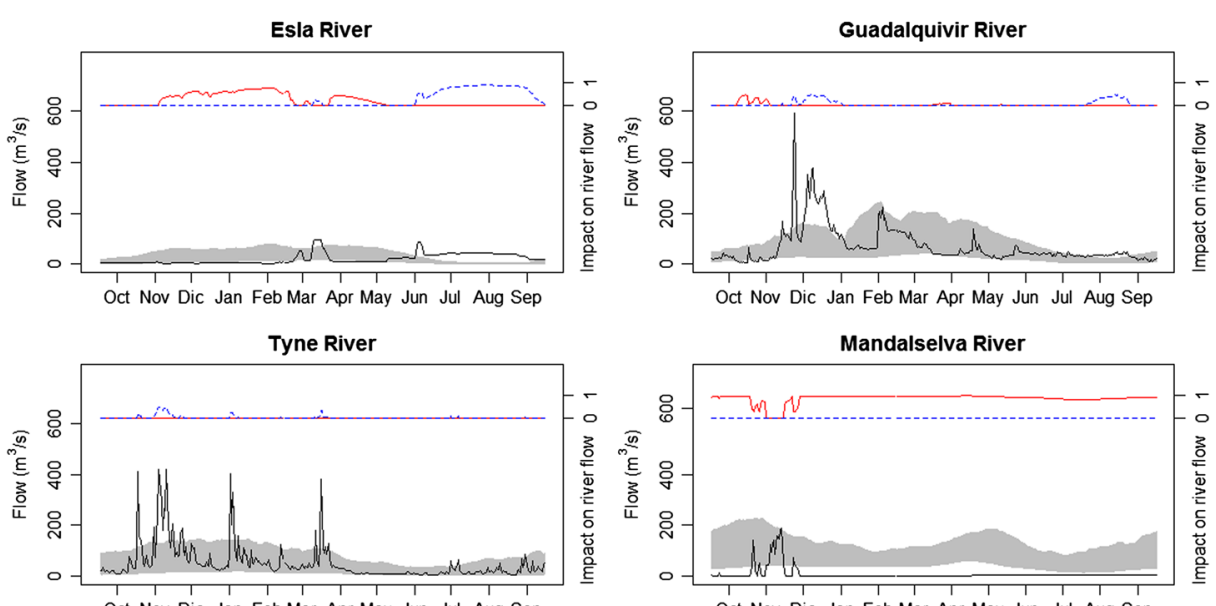

\begin{tabular}{ll}
- & River flow in 2010 \\
& Admissible range of flow variability \\
\hline & Low-flow Impact \\
\hline-- High-flow Impact
\end{tabular}

Fig. 2 Estimated High and Low Environmental impacts of regulated flows of 2010 in the studied sites. At the top of each graph, the red continuous and blue dashed lines show the High- and Low- impacts. At the bottom of each graph, the grey area shows the admissible range of regulated flow variability and the black line shows the circulating regulated flow in 2010

1, the subtraction between current flow and reference flow is divided by the maximum value of the current flow and the reference flow.

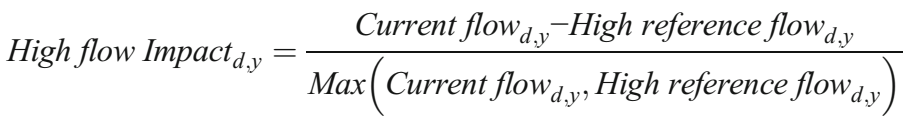

$$
\begin{aligned}
& \text { Low flow Impact } \text { Imy }_{d,}=\frac{\text { Low reference flow } w_{d, y}-\text { Current flow }_{d, y}}{\text { Max }\left(\text { Low reference flow } \text { fly }_{d,}, \text { Current flow }_{d, y}\right)}
\end{aligned}
$$

In addition to changes in magnitude and timing of flows, their duration is also considered when assessing the environmental impact. In this case, moving averages of daily discharges for three, seven and thirty consecutive days are used. Finally, High-flow and Low-flow impacts are estimated using the average of the impacts for one, three, seven and thirty days.

\subsection{Estimation of Environmental Costs of Flow Regulation}

The proposed methodology aimed to assess environmental water costs proportionally to the caused environmental impact, in agreement with the "polluter-pays principle". Therefore, the environmental costs should be related to the price that users of regulated water should pay as being financially liable for their activity causing the environmental damage (EC, European Commission 2004).

Daily environmental costs are calculated following Eq. 3:

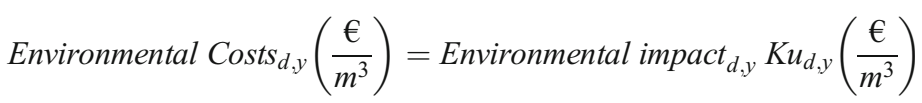


where ' $K u$ ' is a coefficient that transforms the non-dimensional daily environmental impact into environmental costs in monetary terms. According to the coefficient ' $K u$ ', which is calculated following Eq. 4, the relationship between environmental impact and environmental costs can be directly proportional or exponential, according to specific temporal or spatial river-site constraints.

$$
K u_{d, y}\left(\frac{€}{m^{3}}\right)=a_{d, y}\left(\frac{€}{m^{3}}\right) \exp ^{b_{d, y} \text { Environmental Impact }} \text { In }
$$

where ' $a$ ' is a coefficient measured in euros per cubic meter and represents the current unit price of water. This current water unit price may take different values according to different criteria (e.g., operation and maintenance costs, water availability or socio-economic constraints). ' $b$ ' is another coefficient that determines the exponential relationship between environmental cost and environmental impact. It allows capturing the vulnerability or desired conservation level of the river, and it may vary daily or seasonally according to specific ecological or biological constraints. ' $b$ ' takes the value 0 if the minimum value of vulnerability or conservation interest is considered and increases according to the desired environmental status of the river.

Water costs in agriculture are often estimated at annual basis and per hectare. Equation 5 shows an example of how our approach could be used to estimate the annual environmental costs per irrigated hectare, as the product of the annual volume of water devoted to irrigation $\left(V_{y}\right)$ and the accumulated daily environmental costs, divided by the total number of irrigated hectares:

$$
\text { Annual Environmental } \operatorname{Costs}_{y}\left(\frac{€}{h a}\right)=\frac{V_{y}\left(m^{3}\right) \sum_{d=1}^{d=365} \text { Environmental Costs }_{d, y}\left(\frac{€}{m^{3}}\right)}{\text { Total irrigated land }(h a)}
$$

\section{Case Studies}

The proposed methodology has been applied to four river case studies. The full application of the method is only implemented in two cases in Spain from which details of current water prices and users were available.

\subsection{Selected Dam Sites and Available Data}

Two studied sites are located in Spain corresponding to Mediterranean conditions whereas the other two sites are located in Northern European regions (United Kingdom and Norway). Together they cover a large range of flow conditions and dam purposes.

The Esla River is studied at the Riaño dam (northern Spain) which operates since 1988 with a storing capacity of $664 \mathrm{hm}^{3}$. The Riaño reservoir is partially used to produce hydroelectricity but its main use is agricultural irrigation. Flow data exist from 1965 to 2012. (Data available at http://chduero.es/). The Guadalquivir River (Southern Spain) has been studied at the Pedro Marín dam which operates since 1954. This dam has a small storage capacity (i.e., $19 \mathrm{hm}^{3}$ ) but water releases are strongly affected by the Tranco de Beas dam, located upstream and built in 
1944. This dam has a capacity of $498 \mathrm{hm}^{3}$ mainly devoted to irrigation. Flow data for this river-site exists since 1912. (Data available at http://ceh-flumen64.cedex.es/anuarioaforos).

The selected site on the Mandalselva River is located in Laudal, Vest-Agder (Norway). The dam was built in 1981 and the reservoir has a capacity of $1.5 \mathrm{hm}^{3}$ primarily used for hydroelectricity (Data from 1958 to 2013 from http://frendelause.azurewebsites.net/). The studied site on the River Tyne is located in the Kielder reservoir in Falstone, Northumberland (United Kingdom). The dam was built in 1981 and the reservoir has a capacity of $200 \mathrm{hm}^{3}$, directed to household water supplies (Data from 1957 to 2012 from http://nrfa.ceh.ac.uk/).

\subsection{River Regulation and Water Pricing in Spain}

River regulation is particularly intensive in Spain with over 1300 large dams (MMA, Ministerio Medio Ambiente 2006) causing serious environmental impacts (e.g., Vericat and Batalla 2006; González del Tánago et al. 2015). Irrigation is one of the main purposes of river damming in Spain, using more than $80 \%$ of the stored water in the Southern basins (e.g., Martín-Ortega et al. 2011).

Water pricing is very variable across Europe depending on water availability, use and sources (see Berbel et al. 2007). In Spain, water is public domain and water tariffs are annually estimated by the respective Water District according to official guidelines at the national level (see BOE, Boletín Oficial del Estado 2001). All uses of regulated flows (e.g., domestic supply, irrigation) must pay a "canon of regulation", which compensates for the investment and maintenance costs of the infrastructure owned by the State (e.g., dams, reservoirs irrigation canals) and pays for other administrative costs. For domestic supplies, water tariffs are increased by complementary fees directed to wastewater treatment costs. In the case of water for irrigation, water tariffs are only related to the canon of regulation. Each year, the total amount of stored water available for irrigation is quantified, taking into account the total amount of water in the reservoirs and the predicted supply for domestic use and other demands. Total costs of water regulation and distribution are estimated using average values from antecedent years and they are equally distributed among users. In the case of water for irrigation, unitary prices (e.g., euros per irrigated hectare) are calculated considering the total irrigated area and the expected benefits from the irrigated farmlands. This unitary price is calculated every year and may be different among water districts and irrigated areas. For example, in the Guadalquivir Water District, water tariffs for irrigation in 2016 have been estimated within a range of 72.5 and 100.5 euros per hectare (www.chguadalquivir.es). This water pricing approach only covers the operation and maintenance costs of infrastructure and does not fulfil the requirements of the WFD's full cost recovery (e.g., resource costs, referred to the opportunity costs of competing water uses (Martín-Ortega et al. 2011) and environmental costs arising from the environmental damage of flow regulation needed for irrigation).

\section{Results}

\subsection{Admissible Range of Regulated Flow Variability}

Figure 1 shows the admissible range of regulated flow variability estimated for the studied sites. The smoothed red line corresponding to the 10th percentile of daily flows broadly 
covered the fluctuation of minimum flows, whereas the 90th percentile line eliminated from the admissible range a much wider range of natural fluctuations in maximum flows. Nevertheless, when considered together they represent the complete natural flow variability of each river, reflecting the influence of geographical characteristics (e.g., climate, geology) on magnitude, timing and variability of the average natural daily flows.

\subsection{Environmental Impact of Flow Regulation}

The environmental impact of regulated flows is presented in Fig. 2. In the case of the Mediterranean reservoirs where flow regulation is mainly devoted to irrigation (Esla and Guadalquivir rivers), the environmental impacts are seasonal, and they are due primarily to lower flows in winter (water storage period) and higher flows in summer (irrigation period). Deviations from the admissible range of the highest flows during 2010, likely associated with high rainfall natural events, resulted in small high-flow-environmental impacts as a consequence of their relatively short duration (e.g., winter peak-flows observed in the Esla and Guadalquivi rivers). In contrast, deviations in the magnitude of flows responding to regulation patterns lasted for much longer periods, and they resulted in much higher low-flow impacts in winter and high-flow impacts in summer.

The Esla River graph shows the influence of the duration of flows in the calculation of environmental impact. In 2010, the river exhibited a peak flow in June that was far higher than any day in July or August. Nevertheless, despite the magnitude of the peak flow in June being higher than any day in July or August, the High-flow impact in July and August was higher than in June. This is due to the fact that while the duration of the peak flow in June was rather short, the high flow in July and August was very long and constant.

In the case of the Tyne River, the environmental impacts in 2010 were evenly distributed throughout the year and resulted in relatively small deviations from the admissible range of regulated flow variability as a result of short duration floods. In the opposite case of the Mandaselva River, circulating flows in 2010 were extremely low during most of the year, and consequently the environmental impact was noticeably high.

\subsection{Calculating the Environmental Costs of Flow Regulation}

To demonstrate the applicability of our methodology, different values of ' $\mathrm{Ku}$ ' have been considered that represent different scenarios of water unit price and river vulnerability, environmental objectives, or economic constraints (see Eq. 4). The resulting daily environmental costs of the 2010 regulated flow for the studied rivers are shown in Fig. 3. The curves show the variation of the environmental costs throughout the year, representing only an example of 'Ku' values which depend on the values of coefficients ' $a$ ' and 'b' of Eq. 4 and should be specific to each river.

The annual environmental cost of flow regulation has been calculated only in the Spanish cases, for which data on water unit prices, volume of regulated water, and irrigated land were available. Table 1 shows the resulting environmental costs of flow regulation in 2010. In our examples, the value of the 'a' coefficient in Eq. 4 has been considered equal to the official canon of regulation, which has to be paid annually by the respective irrigators using the Esla and Guadalquivir rivers (data available at www.chduero.es and www.chguadalquivir.es). According to the respective environmental impacts of the circulating flows in 2010, the 

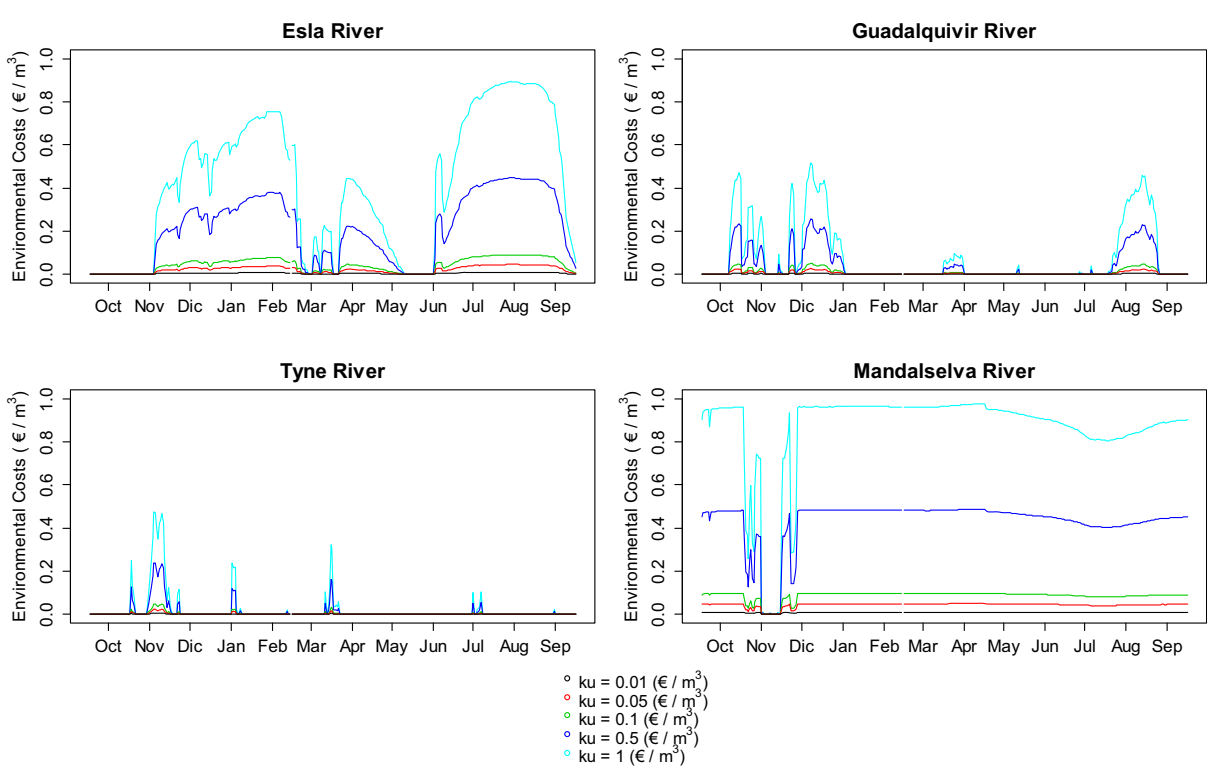

Fig. 3 Daily environmental costs of 2010 regulated flow considering different values of the coefficient $\mathrm{Ku}$, which includes different weights of river vulnerability, conservation status, or other special constraints

environmental costs were much higher for the Esla River than for the Guadalquivir River. It is important to emphasize that these values can vary considerably from year to year.

\section{Discussion}

The proposed methodology represents an innovative approach to assess the environmental costs of flow regulation by dams and reservoirs. It is based on the polluter-pays principle and assesses the environmental costs as a function of environmental impact, estimated according to deviations from the natural flow regime. Environmental impacts are transformed into environmental costs by a function that allows the inclusion of specific spatial (e.g., conservation

Table 1 Environmental costs related to the circulating flows in the Esla and Guadalquivir rivers in 2010, considering different scenarios of potential vulnerability (different values of coefficient ' $b$ ')

\begin{tabular}{lllll}
$\begin{array}{l}\text { Volume of water devoted to } \\
\text { irrigation } \\
\left(\mathrm{hm}^{3}\right)\end{array}$ & $\begin{array}{l}\text { Irrigated } \\
\text { land } \\
\text { (ha) }\end{array}$ & $\begin{array}{l}\text { Coefficient } \\
\text { ' } a \text { ' }\end{array}$ & $\begin{array}{l}\text { Coefficient } \\
\text { ' } b \text { ' }\end{array}$ & $\begin{array}{l}\text { Environmental } \\
\text { costs } \\
\left(€ \mathrm{ha}^{-1}\right)\end{array}$ \\
\hline $77.9^{\mathrm{a}}$ & $11,200^{\mathrm{a}}$ & $0.0045^{\mathrm{a}}$ & 1 & 25.72 \\
& & & 2 & 52.53 \\
& & & 3 & 110.44 \\
$1877.1^{\mathrm{b}}$ & $509,271^{\mathrm{b}}$ & $0.0190^{\mathrm{b}}$ & 1 & 8.37 \\
& & & 2 & 11.91 \\
& & & 3 & 17.14 \\
\hline
\end{tabular}

Esla River
(Esla Canal Irrigation
area)
Guadalquivir River $1877.1^{\mathrm{b}}$
(Guadalquivir
Irrigation area)
a Data obtained from the Duero Water Authority
${ }^{\mathrm{b}}$ Data obtained from the Guadalquivir Water Authority


status of river sites) and temporal (e.g., breeding season, drought periods) circumstances that should influence water pricing policy.

The relevance of our study lies in: $(i)$ the application of the polluter-pays principle strongly recommended by the WFD, focusing on the concept of "user pays" as opposed to "ability to pay"; (ii) the objectivity when assessing the environmental impact of flow regulation according to deviations from the natural flow regime, an calculating environmental costs proportionally to the impacts; (iii) the flexibility of the approach in valuing costs according to spatiotemporal specific river constraints; and (iv) the use of simple graphs and calculations that facilitate transparency and stakeholder communication.

The methodology is very flexible and potentially applicable to all types of impounded rivers. The approach evaluates the environmental costs of mean daily flow alterations. Therefore, it does not consider the costs of flow alterations occurring at smaller time scales, such as hydro-peaking (e.g., hourly fluctuations). Furthermore, the procedure is primarily intended to evaluate the environmental costs of flow regulation due to irrigation that causes flow alterations at broader time scales (e.g., monthly or seasonal scale). Rivers regulated for irrigation often have lower flows (compared to natural values) during the cold and wet period when reservoirs are being filled, and flows are significantly higher than natural values during the warm and dry months, when irrigation demands occur. During the spring and summer, water consumption can be very high and poor water management combined with low productivity can worsen the environmental impact (e.g., García-Vila et al. 2008). Farmers with exchange agreements or water rights generally pay very low prices, and political forces exert a pervasive influence on irrigation subsidies. This can distort agricultural water pricing, where economic factors usually only refer to irrigation infrastructure and maintenance (e.g., Raju et al. 2000) and hinder the full cost recovery (Cooper et al. 2014).

Our proposed approach offers some important advantages over non-use value valuation techniques such as stated preference approaches (e.g., choice experiments and contingent valuation methods; Birol et al. 2006; Hanley and Barbier 2009). This is because our methodology first quantifies and treats the environmental impact as a continuous variable and then sets the cost proportionate to the environmental impact. This is not possible with stated preference approaches because respondents are asked about discrete changes in the environmental status of a good or service. For example, in the Guadalquivir River Basin, Martín-Ortega et al. (2011) conducted a choice experiment using different scenarios characterized by several water flow levels, different environmental impacts, and different frequencies of water restrictions, to evaluate environmental and resource costs. In their study, environmental impact caused by water abstraction for irrigation was qualitatively assessed by four categories of levels of ecological status related to water flow. The ecological status of rivers was considered only in terms of water levels (i.e., magnitude of flows), but deviations in timing and duration of flows (crucial for completing the life-cycles of biological communities) were not taken into account. This example highlights some limitations of using stated preference methods that tend to simplify the number of factors producing environmental impacts. Nevertheless, the findings of Martín-Ortega et al. (2011) are very valuable stating that consumers are willing to accept increases in their water bills of up to $50 \%$ to improve river's ecological status. These findings are in agreement with our estimate of the environmental costs of flow regulation in the same river basin.

One of the main constraints of our proposed methodology is the way the range of admissible regulated flow variability is defined. Other thresholds apart from the 10th and 90th percentile (e.g., during drought periods) could be used. Despite the need to use a percentile value, its precise determination still remains open to discussion. Moreover, the flow 
data from pre-dam years might correspond to periods with rainfall and temperature regimes or land cover patterns that produced hydrological responses different from current conditions (e.g., Iglesias et al. 2005; Lorenzo-Lacruz et al. 2012). This requires a periodic updating of the admissible range of regulated flow variability, in which hydrologic modelling may play an essential role by incorporating climatic variability scenarios.

Despite having a very different approach, our methodology has a similar basis as the seasonal water pricing model presented by Pesic et al. (2013), addressed to reducing the excessive use of fresh water in the city of Belgrade. Their ex-post price determination aims to shift consumers towards rationality and enables water managers to cover peak-season costs without complex calculation procedures. Our methodology allows assessing scenarios that have diverse environmental impacts (e.g., alternatives of flow regulation with less deviation from the admissible range) and their associated environmental costs, which greatly facilitates information-sharing and discussion among stakeholders and policy makers. Additionally, it enables the determination of when high environmental cost may be profitable, i.e., high water productivity compensates for environmental damage, as described in the WFD. Other alternatives, such as the use of different crops with reduced water demands, or different water storage measures separated from the natural river channels (e.g., pools within farmlands that could be filled during the wet period, e.g., Newburn et al. 2011) could lead to a notable reduction in environmental impact and become economically and environmentally viable.

According to our review of the environmental costs of water use, the damage from flow regulation by dams and reservoirs still has not been included in the WFD's water economic analysis (e.g., WATECO 2003; Berbel et al. 2007; 2011). According to WFD regulations, ignoring the environmental costs associated with the environmental damage of dams and reservoirs represents environmental thievery that must be properly highlighted and opened to social discussion (Bithas 2006). In this sense, we stress that the environmental costs of flow regulation should be included in the total economic assessment of water pricing for agriculture. Our approach offers an intuitive methodology based on user-pay principles and follows Cooper et al. (2014) best-practice pricing principles, such as administrative simplicity, transparency, and flexibility.

Finally, we argue that the environmental costs of flow regulation need to be included in agricultural water policy, especially in the Mediterranean and other water-stressed regions profoundly altered by dams and reservoirs (e.g., Grantham et al. 2014; Piqué et al. 2016), water competition is among the highest in the world (e.g., Grindlay et al. 2011; Pérez-Blanco et al. 2015), and pricing faces additional difficulties: there is strong social and political resistance to restricting water allocation to existing irrigation uses for environmental protection (e.g., Grantham et al. 2014).

\section{Conclusions}

Dams and reservoirs can be extremely disruptive to river ecosystems, and their environmental damage needs to be included in water pricing policy. However, the environmental costs of flow regulation have been excluded from economic analysis until now. This study presents a novel approach to assessing the environmental costs of flow regulation based on the polluter-pays principle, in which the environmental cost is proportional to the environmental impact. The main advantages of our approach are as follows: it relies on registered hydrological data, avoiding subjectivity in assessing the environmental impact of regulated flows and promoting transparency and communication among stakeholders; it includes mechanisms to score environmental costs according to the vulnerability of certain reaches or periods when alteration of natural flow 
regimes may be more critical, promoting adaptive approaches to water pricing among stakeholders. We argue that by introducing mechanisms for calculating the environmental costs of regulated flows (which increase proportionally or exponentially to deviations from the natural flow regime) we can encourage more rationality in water resources management. Particularly, charging for the environmental costs of flow regulation would promote improved efficiency in irrigation which could lead to a more environmentally sustainable rural development.

The methodology represents a practical tool for water users and managers and helps optimize the magnitude, timing and duration of flows released by dams. In this sense, it works as a mechanism of self-control to avoid further degradation in regulated rivers. Water authorities may use this approach to justify environmental fees and water prices that foster the full cost recovery of water services, taking into account the "polluter-pays principle". Finally, the methodology can be enhanced after being applied in future research to a number of rivers with distinct regional and socio-economic settings.

Acknowledgements The work leading to this paper was funded by the EU FP7 REstoring rivers FOR effective catchment Management (REFORM) project (Grant Agreement No. 282656).

Open Access This article is distributed under the terms of the Creative Commons Attribution 4.0 International License (http://creativecommons.org/licenses/by/4.0/), which permits unrestricted use, distribution, and reproduction in any medium, provided you give appropriate credit to the original author(s) and the source, provide a link to the Creative Commons license, and indicate if changes were made.

\section{References}

Balana BB, Vinten A, Slee B (2011) A review on cost-effectiveness analysis of agri-environmental measures related to the EU WFD: key issues, methods, and applications. Ecol Econ 70(6):1021-1031

Bateman IJ, Carson RT, Day B (2004) Economic valuation with stated preference techniques: a manual. Edward Elgar Publishing Ltd, Cheltenham, 480pp

Berbel J, Calatrava J, Garrido A (2007) Water pricing and irrigation: a review of the European experience. Irrigation water pricing policy: the gap between theory and practice. CABI, IWMI, 295-327

Berbel J, Martin-Ortega J, Mesa P (2011) A cost-effectiveness analysis of water-saving measures for the water framework directive: the case of the Guadalquivir River basin in southern Spain. Water Resour Manag 25(2): 623-640

Birol E, Karousakis K, Koundouri P (2006) Using economic valuation techniques to inform water resources management: a survey and critical appraisal of available techniques and an application. Sci Total Environ 365(1):105-122

Bithas K (2006) The necessity for environmental taxes for the avoidance of environmental thievery. A note on the paper "environmental responsibility versus taxation". Ecol Econ 56(2):159-161

Bithas K (2008) The sustainable residential water use: sustainability, efficiency and social equity. The European experience. Ecol Econ 68(1):221-229

Bithas K, Kollimenakis A, Maroulis G, Stylianidou Z (2014) The water framework directive in Greece. Estimating the environmental and resource cost in the water districts of western and Central Macedonia: methods, results and proposals for water pricing. Procedia Economics and Finance 8:73-82

BOE (Boletín Oficial del Estado) (2001) Real Decreto Legislativo 1/2001 de 20 de Julio, Texto Refundido de la Ley de Aguas, Art. 114; R.D. 849/1986 de 11 de abril, Reglamento del Dominio Público Hidráulico, Art. 296 to Art. 303 . BOE n ${ }^{\circ} 176$ de 24 de Julio de 2001

Bunn SE, Arthington AH (2002) Basic principles and ecological consequences of altered flow regimes for aquatic biodiversity. Environ Manag 30(4):492-507

Cooper B, Crase L, Pawsey N (2014) Best practice pricing principles and the politics of water pricing. Agric Water Manag 145:92-97

EC (European Commission) (2000) Directive 2000/60/CE of 23 October 2000 establishing a framework for community action in the field of water policy. Official Journal L 327:1-73

EC (European Commission) (2004) Directive 2004/35/CE of 21 April 2004 on environmental liability with regard to the prevention and remedying of environmental damage. Official Journal L 143:56-75 
García-Vila M, Lorite IJ, Soriano MA, Fereres E (2008) Management trends and responses to water scarcity in an irrigation scheme of southern Spain. Agric Water Manag 95(4):458-468

Garrote L, Iglesias A, Granados A, Mediero L, Martin-Carrasco F (2015) Quantitative assessment of climate change vulnerability of irrigation demands in Mediterranean Europe. Water Resour Manag 29(2):325-338

Godinho F, Costa S, Pinheiro P, Reis F, Pinheiro A (2014) Integrated procedure for environmental flow assessment in rivers. Environ Process 1(2):137-147

González del Tánago M, Bejarano MD, García de Jalón D, Schmidt JC (2015) Biogeomorphic responses to flow regulation and fine sediment supply in Mediterranean streams (the Guadalete River, southern Spain). J Hydrol 528:751-762

Grantham TE, Mezzatesta M, Newburn DA, Merenlender AM (2014) Evaluating tradeoffs between environmental flow protections and agricultural water security. River Res Appl 30(3):315-328

Grindlay AL, Zamorano M, Rodríguez MI, Molero E, Urrea MA (2011) Implementation of the European water framework directive: integration of hydrological and regional planning at the Segura River basin, southeast Spain. Land Use Policy 28(1):242-256

GWP (Global Water Partnership) (2000) Integrated water resources management. TAC Background Papers, 4. Stockholm, Sweden. Available at: http://hdl.handle.net/10535/4986

Hanley N, Barbier EB (2009) Pricing nature. Cost-Benefit Analysis and Environmental Policy. Edward Elgar Publishing Ltd, Cheltenham, p 256

Iglesias A, Estrela T, Gallart F (2005) Impactos sobre los recursos hídricos. In: Moreno J (ed) Evaluación preliminar de los impactos en España por el efecto del cambio climático. Ministerio de Medio Ambiente, Madrid, pp 303-352

Lehner B, Liermann CR, Revenga C, Vörösmarty C, Fekete B, Crouzet P, Wisser D (2011) High-resolution mapping of the world's reservoirs and dams for sustainable river-flow management. Front Ecol Environ 9(9):494-502

Lorenzo-Lacruz J, Vicente-Serrano SM, López-Moreno JI, Morán-Tejeda E, Zabalza J (2012) Recent trends in Iberian streamflows (1945-2005). J Hydrol 414:463-475

Martín-Ortega J, Giannoccaro G, Berbel J (2011) Environmental and resource costs under water scarcity conditions: an estimation in the context of the European water framework directive. Water Resour Manag 25(6):1615-1633

MMA (Ministerio Medio Ambiente) (2006) Inventario de Presas Españolas. Publicaciones Ministerio de Medio Ambiente, Madrid

Newburn DA, Brozovic N, Mezzatesta M (2011) Agricultural water security and instream flows for endangered species. Am J Agric Econ 93(4):1212-1228

Pérez-Blanco CD, Delacámara G, Gómez CM (2015) Water charging and water saving in agriculture. Insights from a Revealed Preference Model in a Mediterranean basin. Environ Model Softw 69:90-100

Pesic R, Jovanovic M, Jovanovic J (2013) Seasonal water pricing using meteorological data: case study of Belgrade. J Clean Prod 60:147-151

Piqué G, Batalla RJ, Sabater S (2016) Hydrological characterisation of dammed rivers in the NW Mediterranean region. Hydrol Process 30(11):1691-1707

Poff NL, Zimmerman JK (2010) Ecological responses to altered flow regimes: a literature review to inform the science and management of environmental flows. Freshw Biol 55(1):194-205

Poff NL, Allan JD, Bain MB, Karr JR, Prestegaard KL, Richter BD, Sparks RE, Stromberg JC (1997) The natural flow regime. Bioscience 47(11):769-784

Poff NL, Olden JD, Merritt DM, Pepin DM (2007) Homogenization of regional river dynamics by dams and global biodiversity implications. Proc Natl Acad Sci 104(14):5732-5737

Raju KS, Duckstein L, Arondel C (2000) Multicriterion analysis for sustainable water resources planning: a case study in Spain. Water Resour Manag 14:435

Richter BD, Baumgartner JV, Powell J, Braun DP (1996) A method for assessing hydrologic alteration within ecosystems. Conserv Biol 10(4):1163-1174

Tran LD, Zilberman D, Schilizz S, Chalak M, Kingwell R (2016) Policy implications of managing reservoir water for multiple uses of irrigation and fisheries in southeast Vietnam. Water Utility Journal 13:69-81

Turner RK, Van Den Bergh JC, Söderqvist T, Barendregt A, van der Straaten J, Maltby E, van Ierland EC (2000) Ecological-economic analysis of wetlands: scientific integration for management and policy. Ecol Econ 35(1):7-23

Vericat D, Batalla RJ (2006) Sediment transport in a large impounded river: the lower Ebro, NE Iberian peninsula. Geomorphology 79(1):72-92

Vörösmarty CJ, Meybeck M, Fekete B, Sharma K, Green P, Syvitski JP (2003) Anthropogenic sediment retention: major global impact from registered river impoundments. Glob Planet Chang 39(1):169-190

WATECO (2003) Common implementation strategy for the water framework directive. Guidance document no 1. Economics and the environment. The implementation challenge of the water framework directive, working group 2.6 WATECO, European Communities, Luxembourg 